\title{
Topotype-based DNA Barcode of the Parasitic Isopod Pseudione nephropsi (Bopyridae), with a Supplementary Morphological Description
}

\author{
Keiichi Kakui1 ${ }^{1,4}$, Michitaka Shimomura ${ }^{2}$, Shoichi Kimura ${ }^{3}$, and Taeko Kimura ${ }^{3}$ \\ ${ }^{1}$ Faculty of Science, Hokkaido University, Sapporo, Hokkaido 060-0810, Japan \\ E-mail:keiichikakui@gmail.com \\ ${ }_{2}^{2}$ Seto Marine Biological Laboratory, Kyoto University, Nishimuro, Shirahama, Wakayama 649-2211, Japan \\ ${ }^{3}$ Faculty of Bioresources, Mie University, Tsu, Mie 514-8507, Japan \\ ${ }^{4}$ Corresponding author
}

(Received 18 January 2019; Accepted 12 April 2019)

\begin{abstract}
In 2017, we collected a pair (male and female) of topotypic individuals of the parasitic isopod Pseudione nephropsi Shiino, 1951 from a single nephropid lobster, Metanephrops japonicus (Tapparone-Canefri, 1873), at 310-298 m depth off the eastern coast of the Kii Peninsula, Japan. Based on these specimens, we provide a supplementary description of the male and female morphology, and present mitochondrial cytochrome $c$ oxidase subunit I (COI) DNA barcode sequences. The sequence length amplified with primer pair LCO-1490/HCO-2198 was $658 \mathrm{nt}$, and there were four synonymous nucleotide substitutions ( $0.6 \%$-distance) between the two sequences.
\end{abstract}

Key Words: Crustacea, DNA barcoding, Japan, Isopoda, Nephropidae, North Pacific, parasite.

\section{Introduction}

DNA barcoding (Hebert et al. 2003) is a powerful tool for taxonomy. It enables us to test conspecificity among disjunct populations within widely distributed nominal species (e.g., Tomioka et al. 2016), to test whether two or more taxa showing morphological differences are conspecific (e.g., Cheang et al. 2013), and to link conspecific larvae, juveniles, males, and females in species with large ontogenetic change or sexual polymorphism (e.g., Ota et al. 2012). In addition, DNA sequence data are increasingly being used as the only diagnostic character in species descriptions (e.g., Nakano et al. 2017, 2018), especially for groups having few morphological characters with which to distinguish species. However, in order to use DNA barcoding for species identification or description, a database of sequences is necessary from previously described taxa in the target group.

The genus Pseudione Kossmann, 1881 in the isopod family Bopyridae Rafinesque, 1815 presently comprises 47 species (Boyko et al. 2008 onwards), all of which live as parasites in the gill chamber of astacidean, axiidean, gebiidean, anomuran, or caridean decapods (Boyko et al. 2017). While these isopods show relatively few morphological modifications related to their parasitic mode of life (Williams and Boyko 2012), male and female Pseudione appear simpler in morphology than free-living taxa; for example, some appendages are lacking or reduced (e.g., uropods and pleopods in males), and there are fewer setae on the pereopods. The reduced number of morphological characters for discriminating species in Pseudione can lead to difficulties in species identification using morphology.
Pseudione nephropsi Shiino, 1951 is one of four Pseudione species parasitic on clawed lobsters (Nephropidae, Astacidea) (Horch et al. 2018). This species was originally described from specimens parasitic on the nephropid lobster Metanephrops japonicus (Tapparone-Canefri, 1873) collected from deep water off the coast of Owase in central Japan (Kumano Sea, North Pacific) (Shiino 1951). Markham (1999) later reported this species from a different host, Metanephrops velutinus Chan and Yu, 1991, collected from 401-393 m depth off the eastern coast of Palau Jamdena, Indonesia, in the Arafura Sea $\left(7^{\circ} 45^{\prime} \mathrm{S} 132^{\circ} 42^{\prime} \mathrm{E}\right)$. The disjunct distribution of these two host species (M. japonicus in Japan; M. velutinus from the Philippines to Western Australia; Chan and Yu 1991) and slight morphological differences between the Japanese and Indonesian isopod specimens (Markham 1999) raise the possibility that the Pseudione specimens reported by Markham (1999) may not be $P$. nephropsi. DNA barcoding would be a good way to confirm or reject conspecificity, but no nucleotide sequences for $P$. nephropsi had been deposited in public databases (DDBJ 2018).

During a cruise of the TR/V Seisui-maru (Mie University, Japan) in 2017, a male-female pair of $P$. nephropsi parasitizing an individual of $M$. japonicus was collected off the coast of Owase, the type locality for P. nephropsi. Here we describe or redescribe the morphology of the two sexes, which was incompletely described by Shiino (1951), and report cytochrome $c$ oxidase subunit I (COI) DNA barcode sequences to aid future DNA barcoding in species of Pseudione. 


\section{Materials and Methods}

An individual of Metanephrops japonicus infested by bopyrid isopods was obtained from the Kumano Sea $\left(34^{\circ} 07.753^{\prime} \mathrm{N}, 136^{\circ} 37.934^{\prime} \mathrm{E}\right.$ to $\left.34^{\circ} 07.983^{\prime} \mathrm{N}, 136^{\circ} 37.809^{\prime} \mathrm{E}\right)$ with a biological dredge at $310-298 \mathrm{~m}$ depth on 9 November 2017. The living animals were photographed, and then two branchiae of the host and the whole bodies of the isopods were fixed in $70 \%$ ethanol and preserved in $80 \%$ ethanol. The methods for dissection, preparation of slides, light microscopy, and drawing were as described by Kakui and Angsupanich (2012); after observation, dissected appendages were preserved in $80 \%$ ethanol. The morphological terminology herein follows Markham $(1985,1988)$. The bopyrids studied were deposited in the Invertebrate Collection of the Hokkaido University Museum (ICHUM), Japan (female, ICHUM 5834; male, ICHUM 5835).

Total DNA was extracted from one branchia (M. japonicus), left pereopod 4 (female P. nephropsi), or right pereopod 6 (male P. nephropsi) by using a NucleoSpin Tissue XS kit (TaKaRa Bio, Japan); after extraction, the exoskeletons of the pereopods were recovered and preserved in $80 \%$ ethanol. Part of the COI gene was amplified by PCR using primers LCO-1490 and HCO-2198 (Folmer et al. 1994). PCR amplification conditions with TaKaRa Ex Taq DNA polymerase (TaKaRa Bio) were $94^{\circ} \mathrm{C}$ for $1 \mathrm{~min} ; 35$ cycles of $98^{\circ} \mathrm{C}$ for $10 \mathrm{sec}, 42^{\circ} \mathrm{C}$ for $30 \mathrm{sec}$, and $72^{\circ} \mathrm{C}$ for $50 \mathrm{sec}$; and $72^{\circ} \mathrm{C}$ for $2 \mathrm{~min}$. Methods for sequencing and sequence assembly were as described by Tomioka et al. (2016). The sequences obtained from M. japonicus and the male and female P. nephropsi individuals were deposited in the International Nucleotide Sequence Database (INSD) through the DNA Data Bank of Japan (DDBJ), under accession numbers LC476592, LC476590, and LC476591, respectively. The nucleotide and protein sequences in the INSD most similar to our sequences were determined by BLAST searches (Altschul et al. 1990), using blastn (nucleotide sequences) and blastp (protein sequences) under both the default setting and with the 'Organism' option set to 'Bopyridae.'

\section{Results and Discussion}

Our male and female Pseudione nephropsi specimens were collected from the left gill chamber of the host (Fig. 1A). The male clung to the ventral surface in the region of female pleon surrounded by pleopods when alive (Fig. 1C). Based on our specimens, several morphological characters are described or redescribed as follows.

Female (Figs 1, 2A-H, 3A-D). Creamy white when alive (Fig. 1B, C). Body length $15.5 \mathrm{~mm}$, maximum width $9.5 \mathrm{~mm}$ at pereomere 4; pereon weakly dextral $\left(17^{\circ}\right)$. Head with slight anterior depression, lacking eyes (Figs 1B, 2A); frontal lamina short, narrow. Barbula with elongate, angled outer projection and five small inner projections (Fig. 2B). Antenna 1 with three articles (Fig. 3A). Antenna 2 with eight articles (Fig. 3B, b1); combined length of articles 6-8 ca. 0.3 times length of article 5. Posterolateral point of oostegite 1 rounded at tip (Fig. 2C, D). Anterolateral region of pereomeres 5-7 not projecting laterally. Pereopod 1 (Figs 2E, 3C) with basis bearing dorsoproximal serration; car-

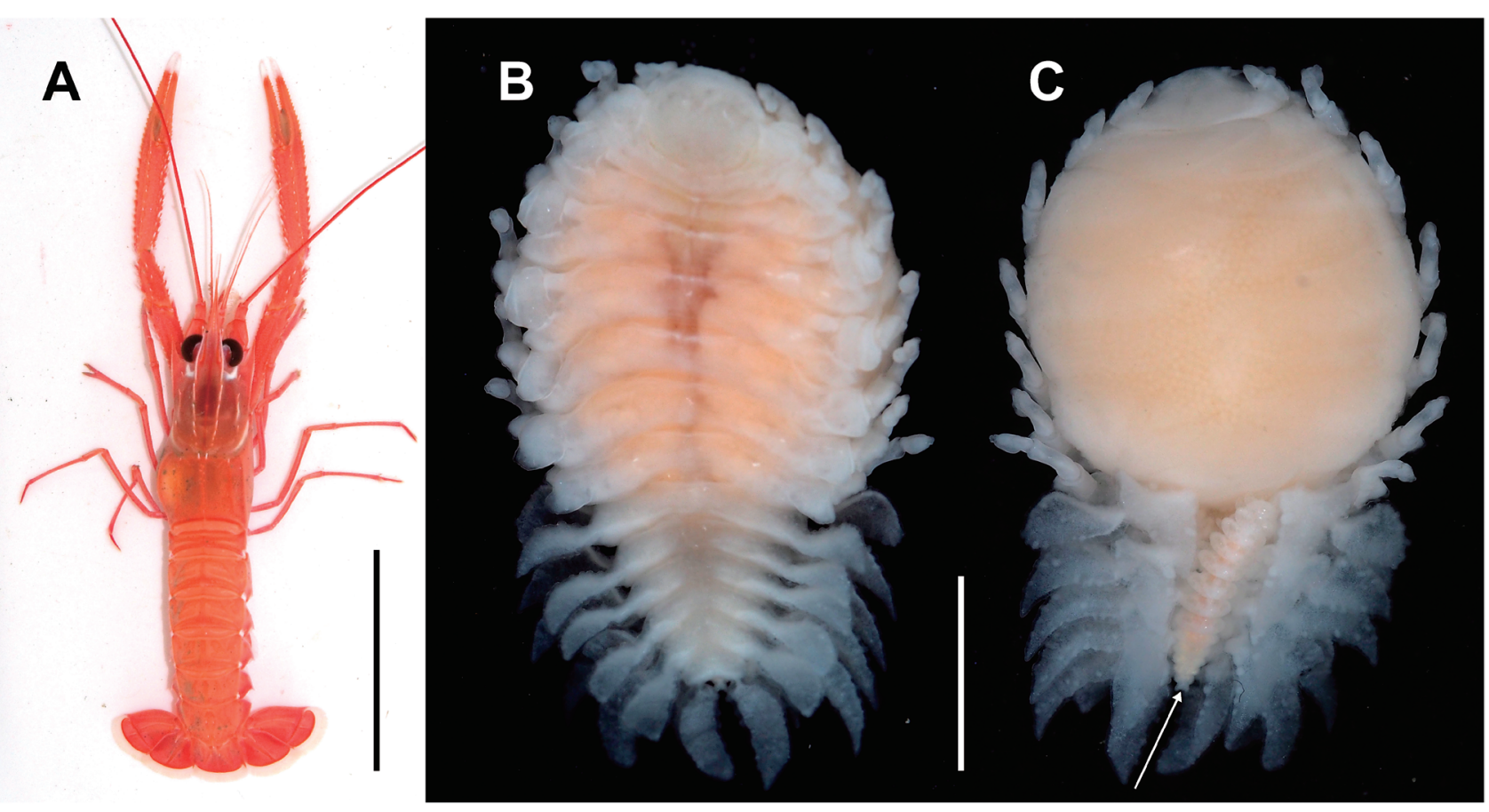

Fig. 1. Pseudione nephropsi Shiino, 1951 parasitizing Metanephrops japonicus (Tapparone-Canefri, 1873), fresh specimens. A, M. japonicus infested by bopyrids; B, C, female P. nephropsi extracted from host, dorsal (B) and ventral (C) views, with attached male (arrow). Scales: $50 \mathrm{~mm}(\mathrm{~A}), 5 \mathrm{~mm}$ (B, C). 
pus with ventrodistal setal cluster. Pereopod 7 (Figs 2F, 3D) with basis bearing several dorsal serrate tubercles; merus and carpus fused; carpus with ventrodistal setal cluster. Five pairs of biramous pleopods, ventrally tuberculate (Fig. 2G). Pleomere 6 with tiny dorsodistal anal cone (Fig. 2H, arrow). Uniramous uropods crenulate; right uropod longer than left
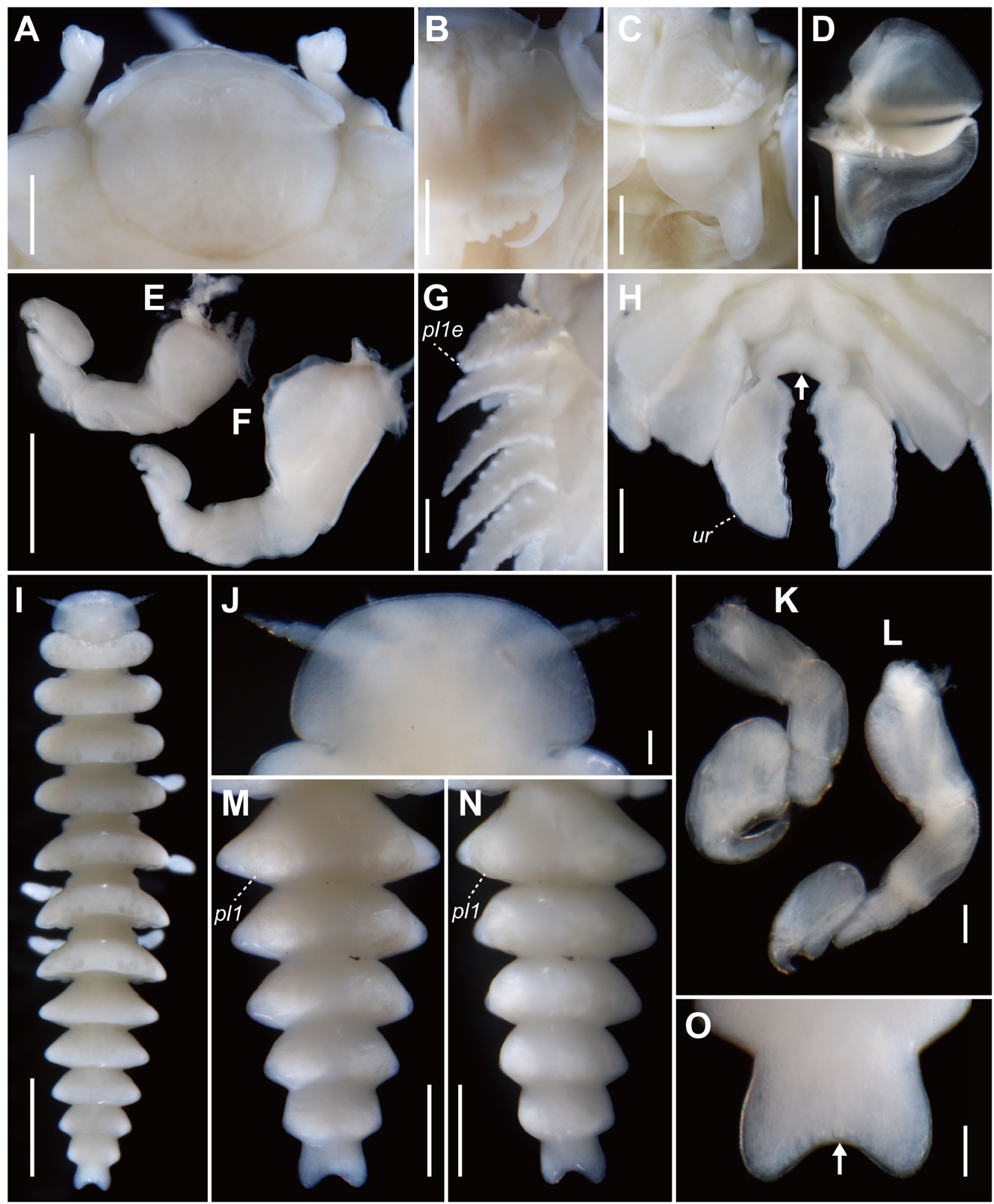

Fig. 2. Pseudione nephropsi Shiino, 1951, fixed specimens. A-H, female; I-O, male. A, head, dorsal view; B, left barbula, ventral view; C, D, left oostegite 1, ventral (C) and dorsal (D) views; E, F, left pereopods 1 and 7, respectively; G, tubercles on right pleopods, ventral view; H, posterior region of body, dorsal view; I, body, dorsal view; J, head, dorsal view; K, L, left pereopods 1 and 7, respectively; M, N, pleon, ventral (M) and slightly-left, ventral (N) views; O, pleomere 6, dorsal view. Abbreviations: pl1, pleopod 1; plle, exopodite of pleopod 1; ur, uropod. Arrows, anal cone. Scales: $1 \mathrm{~mm}(\mathrm{~A}-\mathrm{I}), 0.5 \mathrm{~mm}(\mathrm{M}, \mathrm{N}), 0.1 \mathrm{~mm}(\mathrm{~J}-\mathrm{L}, \mathrm{O})$. 


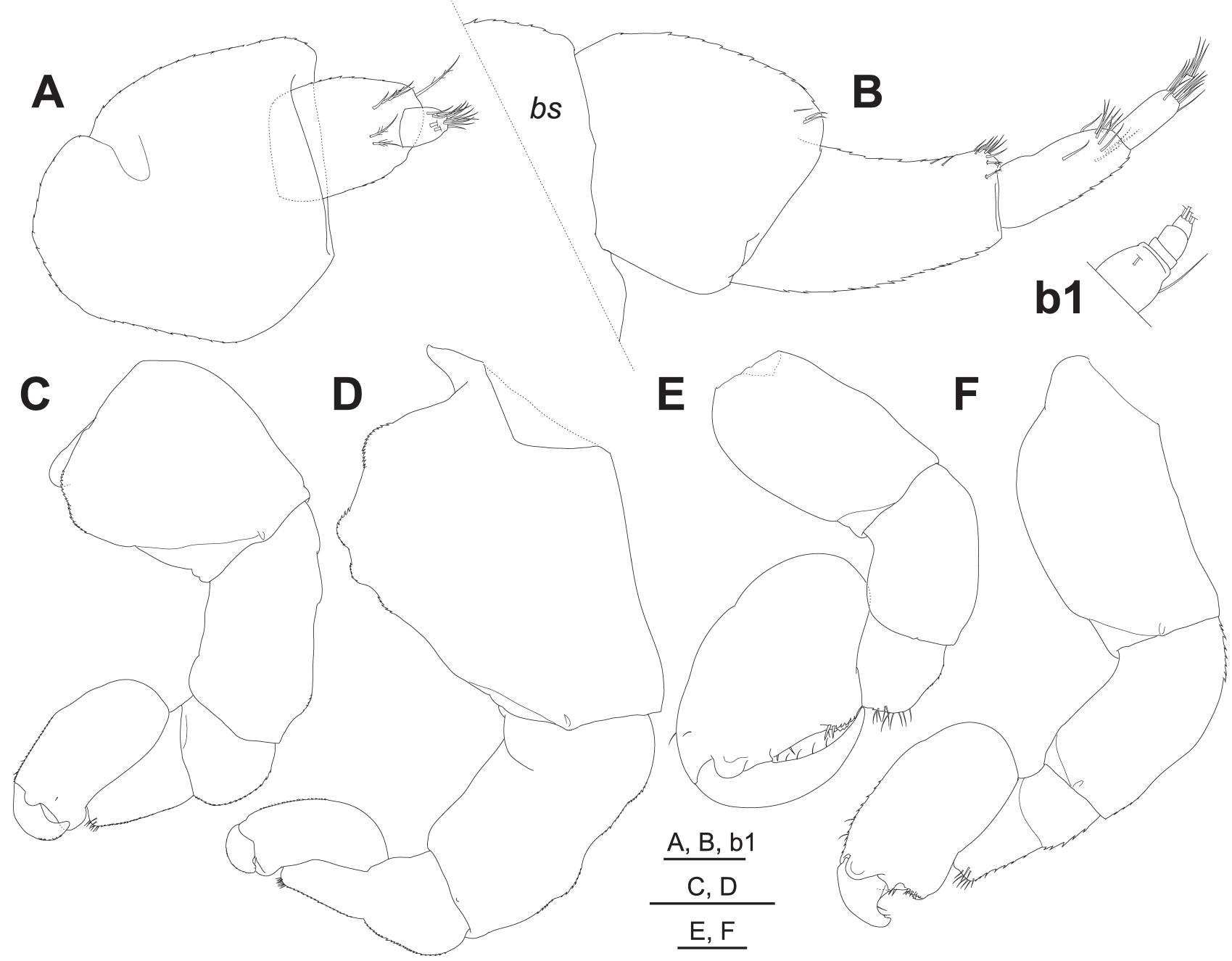

Fig. 3. Pseudione nephropsi Shiino, 1951. A-D, female; E, F, male. A, left antenna 1, ventral view; B, left antenna 2, ventral view, with most portion of basal segment (bs) omitted; b1, distal region of left antenna 2, ventral view, with most setae omitted; C, E, left pereopod 1; D, F, left pereopod 7. Scales: $0.1 \mathrm{~mm}$ (A, B, E, F), $0.05 \mathrm{~mm}$ (b1), $0.5 \mathrm{~mm}(\mathrm{C}, \mathrm{D})$.

(Fig. 2H).

Male (Figs 1, 2I-O, 3E, F). Creamy white when alive (Fig. 1C). Body length $6.2 \mathrm{~mm}$, maximum width $1.3 \mathrm{~mm}$ at pereomere 4 (Fig. 2I). Articulations between cephalon, pereomeres 1-7, and pleomeres 1-4 distinct; those between pleomeres 4-6 indistinct. Width of pereomeres 1-7 remaining nearly constant; pleomeres successively narrower toward posterior end. Head suboval in dorsal view, lacking eyes (Figs 1C, 2J). Pereopod 1 (Figs 2K, 3E) with merus and carpus fused; carpus with ventrodistal setal cluster; ventroproximal region of propodus serrate, with two spiniform setae. Pereopod 7 (Figs 2L, 3F) with merus and carpus not fused; carpus bearing ventrodistal setal cluster; ventrodistal region of propodus serrate, with two spiniform setae. Pleomeres without midventral processes. Pleopods 1-5 appear as low, ventrolateral hemispherical swellings, slightly yellowish in fixed specimen (Fig. 2M, N). Pleomere 6 bilobed, with tiny dorsodistal anal cone (Fig. 2O, arrow).

Our specimens agreed very well morphologically with the types of Shiino (1951). Our female similarly has the ventral tubercles on the pleopods, a round-tipped posterolateral point on oostegite 1 , and the anterolateral regions of pereomeres 5-7 not projecting laterally. Our male similarly has a bilobed pleomere 6 and round pereopods 1-5. Shiino (1951: p. 34 and fig. 6E) found "a structure which is believed to be a lateral plate on the pleotelson of the female though only on one side", but our specimen lacks this structure (Fig. $2 \mathrm{H}$ ). The structure observed by Shiino (1951) might represent an abnormal condition. Shiino (1951) also observed an articulation between pleomeres 4 and 5 in male, whereas we did not. Our male (Fig. 2M, N) has an acute furrow between pleomeres 4 and 5, and Shiino (1951) possibly misidentified this as an articulation.

The partial COI sequences we determined were 658 nt long and can be translated into 219 amino acids. There were four synonymous nucleotide substitutions $(0.6 \% p$ distance) between two sequences. Table 1 lists the top five max-score nucleotide/protein sequences detected by blastn and blastp for our sequences. The blastn results show that $p$ distances among confamilial sequences can reach $26 \%$, and also can be greater than the distance between $P$. nephropsi and taxa in different suborders (e.g., Haloniscus sp.), imply- 
Table 1. Top five max-score nucleotide/protein sequences determined by BLAST searches for our Pseudione nephropsi sequences. IS, identity score; QC, query cover; MS, max score; Ac\#, accession number.

\begin{tabular}{|c|c|c|c|c|c|}
\hline Taxon & IS (\%) & QC (\%) & MS & Ac\# & Reference \\
\hline \multicolumn{6}{|l|}{ Blastn (default setting) } \\
\hline Isopoda sp. & 81 & 81 & 435 & MG936523 & Unpublished \\
\hline Bopyridae sp. & 78 & 93 & 404 & MG936175 & Unpublished \\
\hline Haloniscus sp. & 79 & 84 & 385 & KT236034 & Murphy et al. (2015) \\
\hline Haloniscus sp. & 78 & 84 & 379 & KT236035 & Murphy et al. (2015) \\
\hline Isopoda sp. & 79 & 84 & 375 & HM466415 & Plaisance et al. (2011) \\
\hline \multicolumn{6}{|l|}{ Blastn ("Organism"=Bopyridae) } \\
\hline Athelges paguri (Rathke, 1843)* & 79 & 96 & $467 * *$ & KT208746** & Raupach et al. (2015) \\
\hline Gyge ovalis (Shiino, 1939) & 76 & 96 & 337 & NC_037467 & Yu et al. (2018) \\
\hline Probopyrus pandalicola (Packard, 1879) & 75 & 94 & 316 & MH087672 & Unpublished \\
\hline Bopyroides hippolytes (Krøyer, 1838) & 75 & 84 & 260 & DQ889082 & Costa et al. (2007) \\
\hline Orthione griffenis Markham, 2004 & 74 & 80 & 214 & KP412462 & Unpublished \\
\hline \multicolumn{6}{|l|}{ Blastp (default setting) } \\
\hline Athelges paguri & 93 & 100 & 337 & ALH17253 & Raupach et al. (2015) \\
\hline Gyge ovalis & 94 & 100 & 334 & YP_009477596 & Yu et al. (2018) \\
\hline Decapoda sp. & 89 & 100 & 327 & AWU57895 & Pearman et al. (2018) \\
\hline Malacostraca environmental sample & 93 & 97 & 324 & AKA20637 & Unpublished \\
\hline Probopyrus pandalicola & 89 & 100 & 323 & AWM96874 & Unpublished \\
\hline \multicolumn{6}{|l|}{ Blastp ("Organism"=Bopyridae) } \\
\hline Athelges paguri & 93 & 100 & 337 & ALH17253 & Raupach et al. (2015) \\
\hline Gyge ovalis & 94 & 100 & 334 & YP_009477596 & Yu et al. (2018) \\
\hline Probopyrus pandalicola & 89 & 100 & 323 & AWM96874 & Unpublished \\
\hline Bopyridae sp. & 95 & 94 & 315 & AXR87084 & Unpublished \\
\hline Bopyroides hippolytes & 82 & 95 & 280 & ABK05946 & Costa et al. (2007) \\
\hline
\end{tabular}

*, the IS and QC of three sequences in Raupach et al. (2015) were identical, and only one sequence is presented here; **, sequence with highest max score.

ing nucleotide substitution saturation among bopyrid genera in the COI region sequenced. Blastp detected sequences from confamilial taxa in the default setting, indicating bopyrid protein sequences may be relatively well conserved. The decapod sequence (Decapoda sp.; accession number AWU57895) must have been misidentified or mislabeled, or represent a contaminant.

Here we determined partial COI sequences for $P$. nephropsi based on topotypic specimens. This is the first COI DNA barcode sequence for any species in Pseudione, and will be available to eventually test the identity of the Indonesian P. nephropsi reported by Markham (1999).

\section{Acknowledgments}

We thank Captain Yoichi Maekawa and the crew of TR/V Seisui-maru, and researchers aboard, for their support during the cruise in 2017; Yuki Tanabe for help in molecular work; and Matthew H. Dick for reviewing and editing the manuscript. This study was supported in part by a KAKENHI grant (JP16K18597) to KK from the Japan Society for the Promotion of Science (JSPS).

\section{References}

Altschul, S. F., Gish, W., Miller, W., Myers, E. W., and Lipman, D. J.
1990. Basic local alignment search tool. Journal of Molecular Biology 215: 403-410.

Boyko, C. B., Williams, J. D., and Shields, J. D. 2017. Parasites (Isopoda: Epicaridea and Nematoda) from ghost and mud shrimp (Decapoda: Axiidea and Gebiidea) with descriptions of a new genus and a new species of bopyrid isopod and clarification of Pseudione Kossmann, 1881. Zootaxa 4365: 251-301.

Boyko, C. B., Bruce, N. L., Hadfield, K. A., Merrin, K. L., Ota, Y., Poore, G. C. B., Taiti, S., Schotte, M., and Wilson, G. D. F. (Eds) 2008 onwards. World Marine, Freshwater and Terrestrial Isopod Crustaceans database. Pseudione Kossmann, 1881. Available at: http://www.marinespecies.org/isopoda/aphia.php?p= taxdetails\&id $=118186$ (10 October 2018).

Chan, T.-Y. and Yu, H.-P. 1991. Studies on the Metanephrops japonicus group (Decapoda, Nephropidae) with descriptions of two new species. Crustaceana 60: 18-51.

Cheang, C. C., Tsang, L. M., Chu, K. H., Cheng, I.-J., and Chan, B. K. K. 2013. Host-specific phenotypic plasticity of the turtle barnacle Chelonibia testudinaria: a widespread generalist rather than a specialist. PLoS ONE 8: e57592.

Costa, F. O., deWaard, J. R., Boutillier, J., Ratnasingham, S., Dooh, R. T., Hajibabaei, M., and Hebert, P. D. N. 2007. Biological identifications through DNA barcodes: the case of the Crustacea. Canadian Journal of Fisheries and Aquatic Sciences 64: 272-295.

DDBJ 2018. DNA Data Bank of Japan. Available at http://www.ddbj.nig. ac.jp/index-j.html (10 October 2018).

Folmer, O., Black, M., Hoeh, W., Lutz, R., and Vrijenhoek, R. 1994. DNA primers for amplification of mitochondrial cytochrome $c$ oxidase subunit I from diverse metazoan invertebrates. Molecular Marine Biology and Biotechnology 3: 294-299.

Hebert, P. D. N., Cywinska, A., Ball, S. L., and deWaard, J. R. 2003. Bio- 
logical identifications through DNA barcodes. Proceedings of the Royal Society B 270: 313-321.

Horch, A., Huber, A. F., Araujo, P. B., and Ribeiro, F. B. 2018. A new species of Pseudione Kossmann, 1881 (Isopoda, Cymothoida, Bopyridae) parasitizing the lobster Nephropsis aculeata Smith, 1881 (Decapoda, Astacidea, Nephropidae) in the Southwestern Atlantic. Zootaxa 4461: 245-252.

Kakui, K. and Angsupanich, S. 2012. Birdotanais songkhlaensis, a new genus and species of Nototanaidae (Crustacea: Tanaidacea) from Thailand. Raffles Bulletin of Zoology 60: 421-432.

Markham, J. C. 1985. A review of the bopyrid isopods infesting caridean shrimps in the northwestern Atlantic Ocean, with special reference to those collected during the Hourglass Cruises in the Gulf of Mexico. Memoirs of the Hourglass Cruises 7: 1-156.

Markham, J. C. 1988. Descriptions and revisions of some species of Isopoda Bopyridae of the north western Atlantic Ocean. Zoologische Verhandelingen 246: 3-63.

Markham, J. C. 1999. Crustacea Isopoda: Bopyridae in the MUSORSTOM collections from the tropical Indo-Pacific. II. Species in subfamily Pseudioninae infesting non-anomuran hosts. Mémoires du Muséum National d'Histoire Naturelle 180: $253-$ 265.

Murphy, N. P., Guzik, M. T., Cooper, S. B., and Austin, A. D. 2015. Desert spring refugia: museums of diversity or evolutionary cradles? Zoologica Scripta 44: 693-701.

Nakano, H., Miyazawa, H., Maeno, A., Shiroishi, T., Kakui, K., Koyanagi, R., Kanda, M., Satoh, N., Omori, A., and Kohtsuka, H. 2017. A new species of Xenoturbella from the western Pacific Ocean and the evolution of Xenoturbella. BMC Evolutionary Biology 17: 245 .

Nakano, H., Miyazawa, H., Maeno, A., Shiroishi, T., Kakui, K., Koyanagi, R., Kanda, M., Satoh, N., Omori, A., and Kohtsuka, H. 2018. Correction to: A new species of Xenoturbella from the western Pa- cific Ocean and the evolution of Xenoturbella. BMC Evolutionary Biology 18: 83.

Ota, Y., Hoshino, O., Hirose, M., Tanaka, K., and Hirose, E. 2012. Third-stage larva shifts host fish from teleost to elasmobranch in the temporary parasitic isopod, Gnathia trimaculata (Crustacea; Gnathiidae). Marine Biology 159: 2333-2347.

Pearman, J. K., Leray, M., Villalobos, R., Machida, R. J., Berumen, M. L., Knowlton, N., and Carvalho, S. 2018. Cross-shelf investigation of coral reef cryptic benthic organisms reveals diversity patterns of the hidden majority. Scientific Reports 8: 8090.

Plaisance, L., Caley, M. J., Brainard, R. E., and Knowlton, N. 2011. The diversity of coral reefs: what are we missing? PLoS ONE 6: e25026.

Raupach, M. J., Barco, A., Steinke, D., Beermann, J., Laakmann, S., Mohrbeck, I., Neumann, H., Kihara, T. C., Pointner, K., Radulovici, A., Segelken-Voigt, A., Wesse, C., and Knebelsberger, T. 2015. The application of DNA barcodes for the identification of marine crustaceans from the North Sea and adjacent regions. PLoS ONE 10: e0139421.

Shiino, S. M. 1951. Some bopyrid parasites found on the decapod crustaceans from the waters along Mie Prefecture. Report of Faculty of Fisheries, Prefectural University of Mie 1: 26-40.

Tomioka, S., Kondoh, T., Sato-Okoshi, W., Ito, K., Kakui, K., and Kajihara, H. 2016. Cosmopolitan or cryptic species? A case study of Capitella teleta (Annelida: Capitellidae). Zoological Science 33: 545-554.

Williams, J. D. and Boyko, C. B. 2012. The global diversity of parasitic isopods associated with crustacean hosts (Isopoda: Bopyroidea and Cryptoniscoidea). PLoS ONE 7: e35350.

Yu, J., An, J., Li, Y., and Boyko, C. B. 2018. The first complete mitochondrial genome of a parasitic isopod supports Epicaridea Latreille, 1825 as a suborder and reveals the less conservative genome of isopods. Systematic Parasitology 95: 465-478. 